\title{
SURVEY OF BANNACK STATE PARK AND VICINITY FOR MONTANA PLANT SPECIES OF SPECIAL CONCERN
}

\section{STATE DOCUMENTS COLLECTION}

\section{i998}

MONTANA STATE LIBRARY

1515 C. 6th AVE.

HELENA, MONTANA 59520

\author{
Prepared by: \\ Jim Vanderhorst \\ Montana Natural Heritage Program \\ State Library \\ 1515 East Sixth Avenue \\ Helena, Montana 59620
}

\begin{abstract}
Prepared for:
Bannack State Park

Montana Department of Fish, Wildlife and Parks

4200 Bannack Road

Dillon, Montana 59725
\end{abstract}

\section{January, 1995}
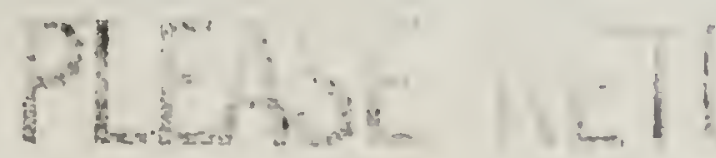


\section{SURVEY OF BANNACK STATE PARK AND VICINITY FOR MONTANA PLANT SPECIES OF SPECIAL CONCERN}

\section{STATE DOCUMENTS COLLECTION}

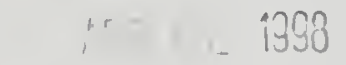

MONTAIA STATE LIBRARY

$1515 \mathrm{E}$. 6th AVE.

HELENA, MONTANA 59520

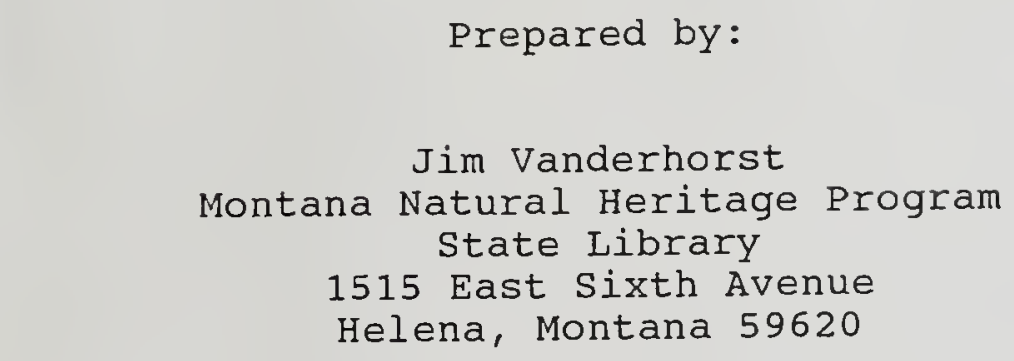

Prepared for:

Bannack State Park

Montana Department of Fish, Wildlife and Parks 4200 Bannack Road

Dillon, Montana 59725

January, 1995

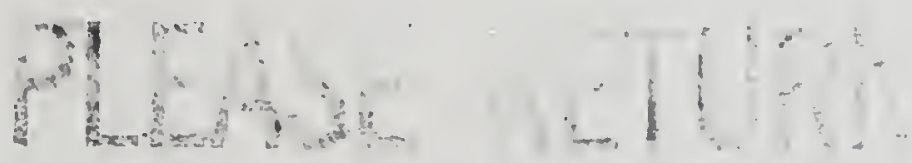


- 1995 Montana Natural Heritage Program

This document should be cited as follows: Vanderhorst, J. 1995. Survey of Bannack State Park and vicinty for Montana plant species of special concern. Unpublished report to Bannack stae Park, Montana Department of Fish, Wildlife, and Parks. Montana Natural Heritage Program, Helena. 
TABLE OF CONTENTS

INTRODUCTION

THE STUDY AREA • . . . . . . . . . . . . . . . . . . . . . . 1

METHODS . . . . . . . . . . . . . . . . . . . . . . . . 5

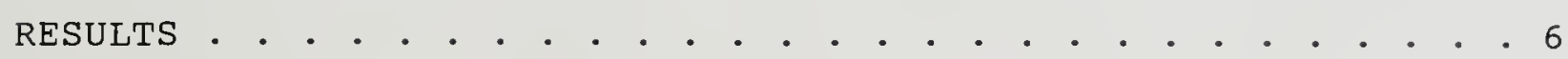

Astragalus scaphoides . . . . . . . . . . . . . 8

Lesquerella sp. novum I . . . . . . . . . . . . . 11

Lomatium attenuatum . . . . . . . . . . . . . . . . 14

Sphaeromeria argentea

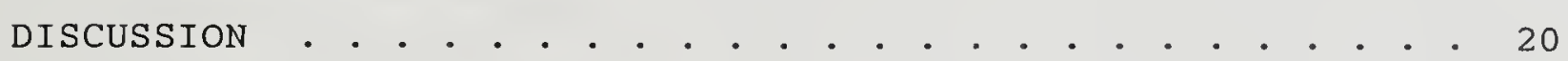

LITERATURE CITED • • . . . . . . . . . . . . . . . . . . . 22

APPENDIX A: Primary search routes . . . . . . . . . . . . . 24

APPENDIX B: Vascular plants of the study area . . . . . . . . 25

APPENDIX C: Photocopy of Cicuta maculata . . . . . . . . . 30

APPENDIX D: Element Occurrence Records and maps . . . . . . . 31

APPENDIX E: Illustrations . . . . . . . . . . . . . . . . . 40

\section{LIST OF FIGURES}

Figure 1. Map of the Bannack State Park vicinity . . . . . . . 3 Figure 2. Map of the main access to Bannack . . . . . . . . . 4 


\section{INTRODUCTION}

In the past several years, the Montana Natural Heritage Program has conducted extensive surveys for rare and sensitive plants on public lands in Beaverhead County and elsewhere in the state. Based on these surveys, previous herbarium collections, publications, and reports, the program maintains a list of Montana plant species of special concern (Heidel 1994). These are plants which are "known or suspected to be rare, endemic, disjunct, threatened, or endangered throughout their range or in Montana." These plants are an important part of Montana's unique state heritage, and documenting their distribution and abundance is the first step to insure their conservation. Recent botanical discoveries in Beaverhead County have included plants not previously known in Montana and plants which have not yet been scientifically described and named. In addition, many species have been found to be more common than previously thought. These discoveries have resulted in many recent changes and proposed changes to the list of Montana plant species of special concern, and are an indication of the relative infancy of botanical study in Beaverhead County.

This report describes a survey of the vicinity of Bannack State Park, Beaverhead County, Montana, for plant species of special state concern. The survey was initiated to insure that specific projects proposed by the park would not impact populations of these plants, however, the opportunity was given to survey the entire park and immediately surrounding BLM lands. Bannack State Park is located in the center of an area known to host several endemic plant species and was thus identified as having a high potential for hosting some of these rare plants. The results of this survey are meant to serve as a botanical baseline to aid in the long term management of Bannack state Park and also to provide an interpretive tool for Bannack's visitors.

\section{THE STUDY AREA}

Bannack State Park lies along Grasshopper Creek, close to the center of Beaverhead County, about $20 \mathrm{miles}$ southwest of the county seat, Dillon. The town was Montana's first territorial capital, and today many visitors are attracted to the remote site by its historical ghost town. Gold was first discovered along Grasshopper Creek in 1862, and soon after, the town of Bannack boomed. The gold did not last long, nor did the designation as territorial capital, but the legacy of gold mining is readily apparent in the overturned streambeds of Grasshopper Creek and extensive bedrock excavations downstream from the abandoned townsite. 
The lode deposits of gold near Bannack were located near the contact of igneous intrusive rocks with massive beds of Madison limestone (Geach 1972). These limestone beds are in a narrow belt of foothills, formed by overthrust faults (Geach 1972), which extend from the Tendoy Mountains to the south, through Bannack, north to the Pioneer Mountains. Bannack is located on the western edge of these foothills, at the entrance to a gorge through which Grasshopper Creek flows. Upstream, to the west of Bannack lies the high intermountain basin of Grasshopper Valley.

The boundaries of the study area include all of Bannack State Park and some surrounding Bureau of Land Management land for which a Recreation and Public Purposes patent application has been filed by the park. This patent would transfer management responsibility of the BLM lands to Bannack state Park (J. Walker, pers. commun.). Figure 1 is a map of the vicinity of Bannack State Park, showing the boundaries of the patent application. Also surveyed was an approximately $3.5 \mathrm{mile}$ stretch of roadside along the main access road to Bannack from the north (Figure 2). The survey was originally commissioned to determine potential impacts to Montana plant species of special concern caused by projects proposed by the park. These projects include 1) road improvements to the main access to the park, 2) a building stabilization project within the Bannack townsite, and 3) a nature trail along Grasshopper Creek.

The native vegetation of the study area is highly correlated with its geology and geomorphology. The ridge of Madison limestone along the eastern border supports mountain mahogany (Cercocarpus ledifolius) and limber pine (Pinus flexilis) communities and a unique assemblage of limestone loving forbs. The lower foothills to the west, underlain by Tertiary basin sediments, are dominated by sagebrush (mostly Artemisia tridentata var. vaseyana) and grasses, including bluebunch wheatgrass (Elymus spicatus) and needle and thread (stipa comata). The native vegetation of the Bannack townsite was probably almost entirely converted during the towns occupancy, but today the lowland big sagebrush (Artemisia tridentata var. tridentata) is becoming reestablished, although introduced species such as Kentucky bluegrass (Poa pratensis) and crested wheatgrass (Agropyron cristatum) are still the predominant grasses. Also persisting in the townsite are many garden remnants such as rhubarb (Rheum Rhabarbarum) and oriental poppy (Papaver orientale). Like the townsite, the floodplain of Grasshopper Creek underwent heavy disturbance in the mining days, but today, riparian communities dominated by willows (Salix spp.), sedges (Carex spp.), and other aquatic plants are again established in some spots and even the droughty tailing piles are slowly reverting to floodplain woodlands dominated by cottonwoods (Populus spp.). 


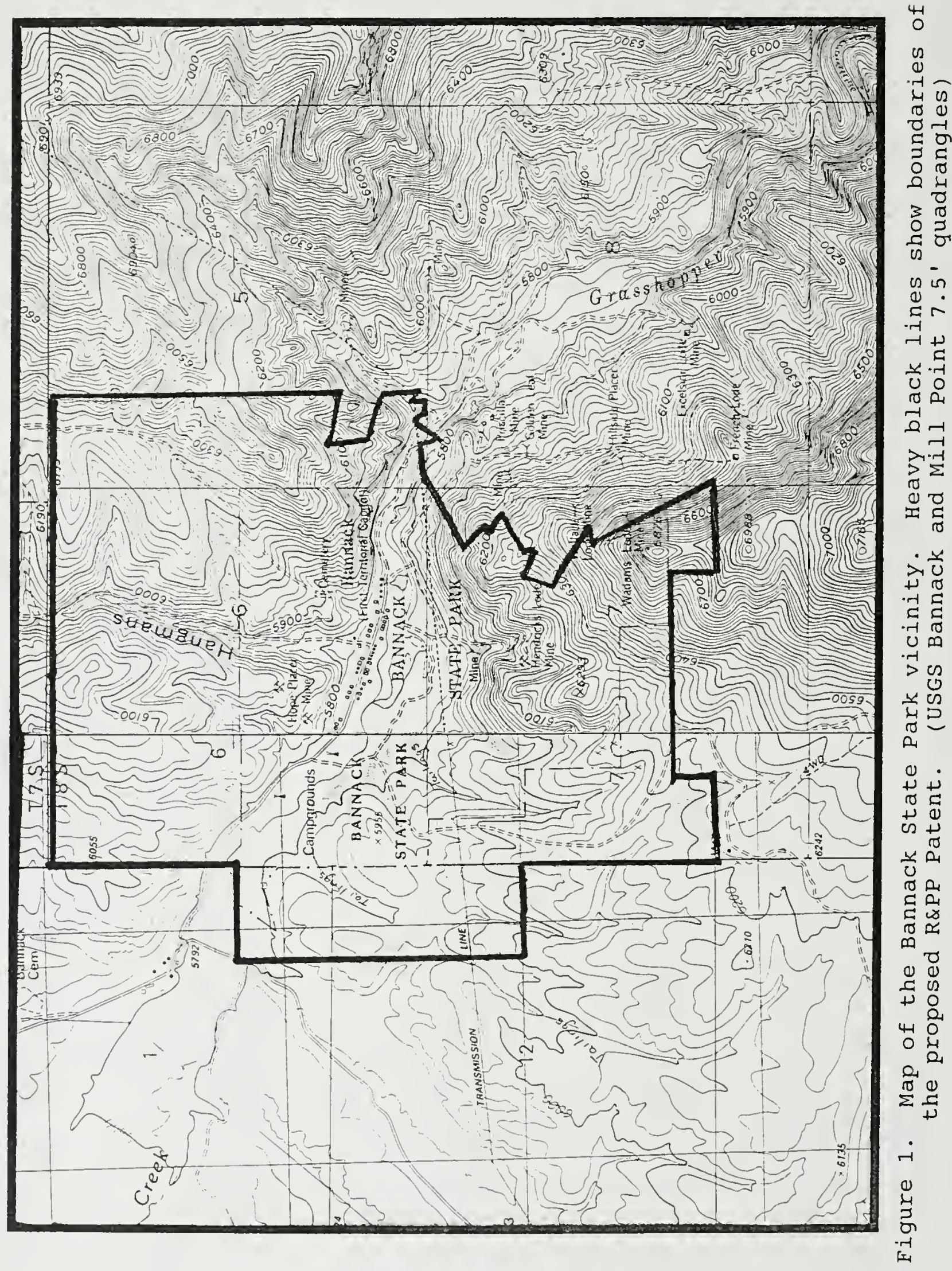




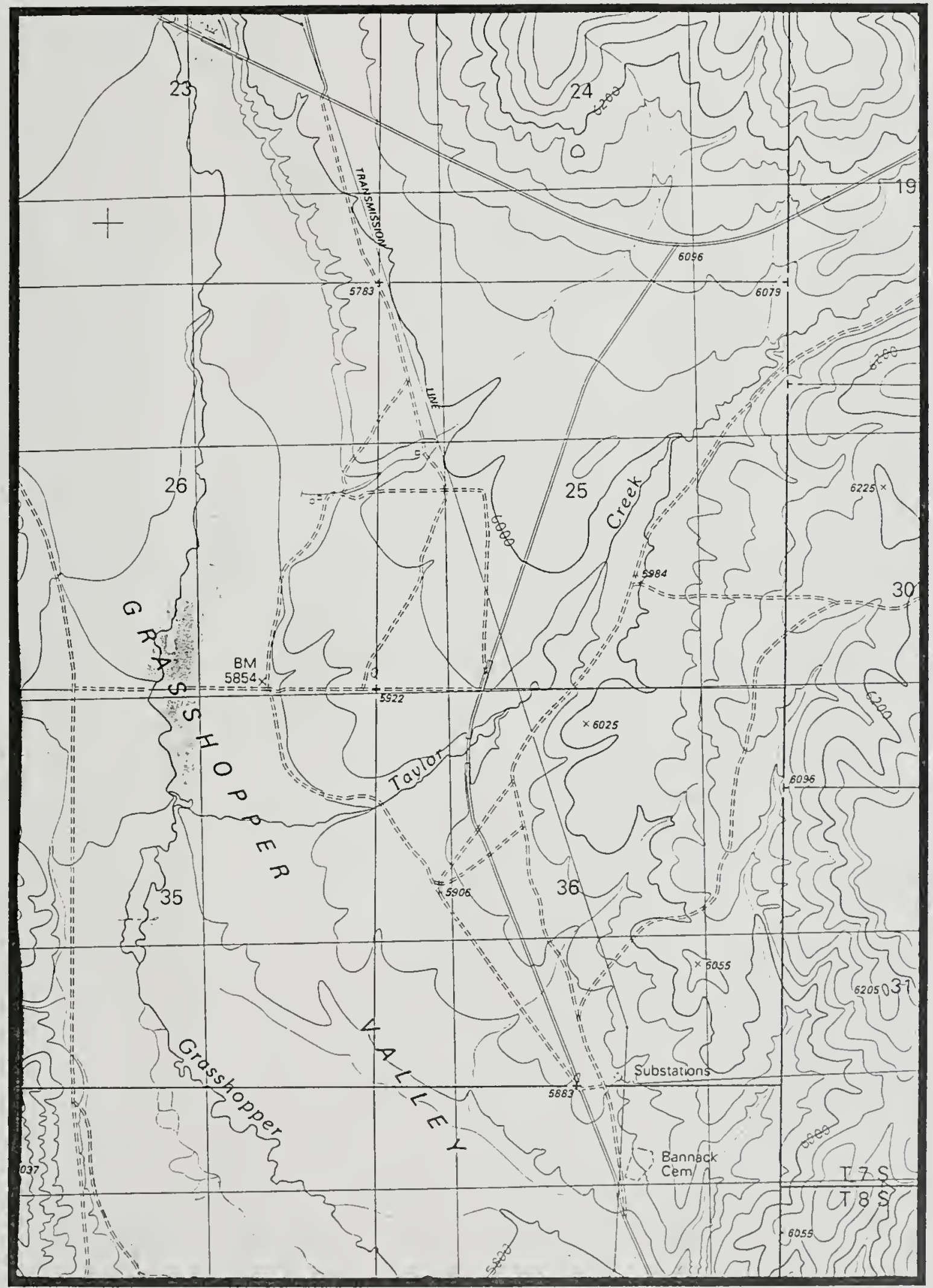

Figure 2. Map showing the main access to Bannack from the north. (USGS Mill Point 7.5' quadrangle) 


\section{METHODS}

Previous botanical surveys of nearby areas in Beaverhead County provided a list of target Montana plant species of special concern for this project to guide timing of fieldwork and selection of habitats to be searched. Included were two species which occur just outside of the park boundaries, Bitterroot milkvetch (Astragalus scaphoides), known from several sites in the Grasshopper Creek drainage downstream, and an undescribed bladderpod (Lesquerella sp. novum I), which was recently found on the limestone ridge overlooking Bannack to the east of Hangman's Gulch (Heidel 1993). Because the areas affected by proposed park projects are mostly sagebrush communities, species of concern which occur in these habitats, such as Bitterroot milkvetch and Lemhi beardtongue (Penstemon lemhiensis), were considered priority targets. A high priority was also given to targets of wetlands, such as Idaho sedge (Carex parryana ssp. idahoa), because proposed road improvement and trail construction are adjacent to these habitats.

I conducted surveys for Montana plant species of special concern in the vicinity of Bannack State Park on June 12, 17, and 30, and August 15 of 1994. All of the proposed project areas were searched, and representative habitats throughout the rest of the study area were surveyed. A map showing the primary search routes in the vicinty of the park is given in Appendix $A$. Figure 2 (on the preceding page) shows the access road to the north which was surveyed.

In order not to overlook species of special state concern and to begin compilation of a floristic list for the park, all vascular plants encountered were identified whenever possible. The primary references used to key out plants in the field were Dorn (1984, 1992) and Hitchcock and Cronquist (1973). Specimens were collected when field identification was difficult and to document populations of sensitive and other notable species. A first set of all collections will be deposited at the herbarium of Montana State University (MONT).

When populations of Montana plant species of special concern were encountered, standard field survey forms were filled out and the populations were mapped. Information was recorded on habitat (associated vegetation, landscape position, soils), demography (population numbers and area covered), plant biology (phenology, vigor, reproductive success), and potential threats to the populations. 


\section{RESULTS}

No Montana plant species of special concern were found in the three proposed project areas or nearby where they would be impacted by the projects. The road improvement and building stabilization projects are located in areas which do not have intact native plant communities. Most of the length of the access road to Bannack is through weedy sagebrush grassland which is heavily trailed by cattle. Some native plants are beginning to recolonize the Bannack townsite, but the area remains dominated by introduced grasses, and no populations of plants of special state concern were found. The primary targets for these project areas, Bitterroot milkvetch (Astragalus scaphoides) and Lemhi beardtongue (Penstemon lemhiensis), were not seen anywhere in the study area, although they would have been easily recognized in flower at the survey dates, and the project areas are not thought to be potential habitat for these species. Potential habitat for these two species which has not been surveyed may occur elsewhere in the park. No species of special state concern were found in the wetlands potentially impacted by the road improvement and trail construction projects. These areas around Grasshopper and Taylor Creeks were surveyed in June and again in August so that late maturing aquatic vegetation could be identified. In addition, the nature trail is well routed to skirt wet areas. None of the proposed projects are expected to significantly impact the native vegetation of the park or its vicinity.

A highly significant botanical site was found in the study area, and although it lies mostly outside of current Bannack State Park boundaries, it is mostly within the boundaries of the Recreation and Public Purposes Patent which has been applied for by the park. This is the limestone ridge to the east of Hangman's Gulch where the undescribed bladderpod (Lesquerella sp. novum I) was previously known. Two more Montana plant species of special concern, tapertip biscuitroot (Lomatium attenuatum) and chicken sage (Sphaeromeria argentea), were found on the same ridge. In addition, two species which are currently in the process of being dropped from listing by the Montana Natural Heritage Program, limestone larkspur (Delphinium bicolor spp. novum) and sword townsendia (Townsendia spathulata), and three species which were recently dropped, King's sandwort (Arenaria kingii), Suksdorf's monkeyflower (Mimulus suksdorfii), and hedgehog cactus (Pediocactus simpsonii) were also found on this ridge. Arenaria kingii, Pediocactus simpsonii, and a third species which was recently dropped from listing, Nevada buckwheat (Eriogonum ovalifolium var. nevadense), were also seen in sagebrush habitats in the vicinities of the park and the access road to the north. These species have been or are being dropped because they have been found by recent surveys, mostly in Beaverhead County, to be more abundant than previously thought and are not thought to be threatened at this time. No other 
Montana species of special concern were found in the study area, but some areas remain unsurveyed.

A total of 145 taxa of vascular plants were identified in the study area (Appendix B). Twenty eight of these, nearly 20\% of the total (a very high percentage), were introduced to this continent. Many of these are potentially serious weeds; of special note is spotted knapweed (Centaurea maculosa) which has become a major threat to native plants and plant communities as well as to agriculture in much of western Montana. Other exotic species, such as rhubarb (Rheum Rhabarbarum) and oriental poppy (Papaver orientale), are garden introductions which pose no threat of becoming invasive in native habitats. There is one native wetland plant found along Taylor Creek, and likely to occur in wet areas in Bannack state Park, which may pose some danger to park visitors. This is water hemlock (Cicuta maculata), which is deadly poisonous; a photocopy of a specimen of the plant is given in Appendix $C$.

The remainder of this section is devoted to summaries of information on the three Montana species of special concern which were found in the study area. Information is also given on Astragalus scaphoides; although this species was not found during this project, it is known from private land just outside park boundaries. Park activities could potentially impact this population or other nearby populations, and the species could possibly occur in the park in habitat which has not been surveyed. Subheadings of the summaries include description, present legal or other formal status, geographic distribution, habitat, and population demography and biology. Management considerations for the species are treated in the discussion section which follows these summaries. Element Occurrence Records which give additional details on the populations, and maps showing the precise locations and boundaries of the populations are included in Appendix D. 
Astragalus scaphoides (Jones) Rydb.

Bitterroot Milkvetch

\section{A. DESCRIPTION}

1. General description: Astragalus scaphoides is a member of an extremely diverse genus in the Fabaceae (Pea or Bean Fanily). The plants are relatively large herbaceous perennials with pinnately compound leaves borne on the flowering stems. The inflorescence is a compact to somewhat elongate raceme of many relatively large, bilaterally symmetrical flowers. The perianth consists of a fused, five lobed calyx and a cream to yellowish corolla which includes a banner (the top segment), two wings (the side segments), and a keel (the boat shaped bottom segment). There are 10 stamens, nine connected in a group and one free, and a single ovary. The mature fruit is a distinctively stalked legume which contains several seeds. An illustration of the species is included in Appendix $\mathrm{E}$.

2. Technical species description (quoted from Hitchcock and Cronquist 1961): Sparsely strigillose perennial with a taproot and branched crown; stems several, stout, ascending to erect, 2-6 dm tall; leaves 10-25 cm long; stipules lanceolate, 1-4 mm long, not connate; leaflets 15-21, lanceoblong to elliptic-oblong, $1.5-3.5 \mathrm{~cm}$ long, as much as $13 \mathrm{~mm}$ broad, glabrous on the upper surface at least; peduncles mostly 10-15 cm long; racemes closely 15 - to 30-flowered but elongating and open in fruit; pedicels 2-5 mm long; flowers spreading to slightly reflexed, white to ochroleucous, about $2 \mathrm{~cm}$ long; calyx usually blackish-hairy, 8-10 mm long, the narrowly lanceolate lower teeth about $2 \mathrm{~mm}$ long; banner erect; wings 2-4 mm longer than the keel; pod erect, with a stout upward-arching stipe about twice as long as the calyx, the body $1.5-2 \mathrm{~cm}$ long, cartilaginous, glabrous, slightly mottled, corrugate-wrinkled, oblong-ovoid, inflated and slightly obcompressed, 4-6 mm broad, 6-10 $\mathrm{mm}$ thick, with both sutures sulcate, the lower intruded to form a $3 / 4$ complete partition.

3. Diagnostic characters: The following combination of characters separates this from other Montana species of Astragalus (adapted from Dorn 1984):

-Leaflets more than 5, not awl shaped

-Hairs attached at their base

- Stipules not united on side of stem opposite the petiole

-Pods stipitate, glabrous, obcompressed with the lower suture nearly forming a partition within the fruit, 7$20 \mathrm{~mm}$ wide, less than 3 times as long as wide -Calyx 8-12.5 mm long, banner more than $15 \mathrm{~mm}$ long 


\section{B. PRESENT LEGAL AND OTHER STATUS}

1. State: The Montana Natural Heritage Program ranks the species G3S1 (Heidel 1994). The global ranking (G3) is a reflection of vulnerability due to a restricted range. Within Montana, the species is considered critically imperiled due to extreme rarity (S1).

2. Federal

a. U.S. Fish and Wildlife Service: $3 C$ (UDSI Fish and Wildlife Service 1993); This signifies that the species has "proven to be more abundant or widespread than previously believed and/or....(is) not subject to any identifiable threat."

b. Bureau of Land Management: proposed sensitive in Montana (USDI Bureau of Land Management 1993).

c. U.S. Forest Service: none; However, sensitive status has been recommended because the species was found for the first time in a National Forest, on the Beaverhead in the Tendoy Mountains in 1994 (Vanderhorst 1995a).

\section{GEOGRAPHIC DISTRIBUTION}

1. Species range: Astragalus scaphoides is a narrow endemic, restricted to the foothills of the Bitterroot Mountains and adjoining valleys in Lemhi County, Idaho and across the mountains in southwestern Beaverhead County, Montana (Barneby 1964).

2. Distribution in Montana: The species is known only from southwestern Beaverhead county. There are a total of 14 occurrences now entered in the Biological Conservation Database in the drainages of Grasshopper, Horse Prairie, and Medicine Lodge creeks and the upper Beaverhead River.

3. Occurrences in the study area: Bitterroot milkvetch was not found in the study area by this project, but a population was surveyed by Peter Lesica in 1983 on private land just east of the park. Additional populations are known nearby to the east further down the canyon of Grasshopper creek and to the south along the road to Grant. An Element occurrence Record and map showing the precise location of the population just to the east of the park are given in Appendix D.

\section{HABITAT}

1. Associated vegetation: In Montana, Bitterroot milkvetch grows in sagebrush grasslands usually dominated by big 
sagebrush (Artemisia tridentata) and bluebunch wheatgrass (Elymus spicatus). Other shrub species which are subdominant or in some cases replace big sagebrush in these habitats include three-tip sagebrush (Artemisia tripartita), low sagebrush (Artemisia nova), and grey rabbitbrush Chrysothamnus nauseosus). Other common or subdominant grasses at the sites include needle and thread (stipa comata), indian ricegrass (Oryzopsis hymenoides), Idaho fescue (Festuca idahoensis), and Sandberg's bluegrass (Poa secunda). Among the most conspicuous associated forbs are other milkvetches, including Astragalus adsurgens, Astragalus drummondii, and Astragalus atropubescens.

2. Topography: Barneby (1964) describes the settings of Astragalus scaphoides throughout its range as "open valleys, low hills, (and) canyon benches ... from 3,500-6,000 feet." This describes the landforms where the species occurs in Montana, however, the elevation at some sites is somewhat higher and populations are often confined to warm, southerly facing aspects or micro-aspects.

3. Soil relationships: In Montana, Astragalus scaphoides grows in relatively well developed, dry soils ranging from clayey to gravelly and stony loams. The soils are derived from limestones, volcanics, and basin sediments. The soil of the occurrence near Bannack is heavy and gravely.

\section{E. POPULATION DEMOGRAPHY AND BIOLOGY}

1. Demographic details: Most populations in the state are small and local, consisting of fewer than 500 plants. The population nearest Bannack was estimated in 1983 to consist of fewer than 50 plants. A population further downstream near the Bon Accord mine was larger, estimated to consist of between 200 and 300 plants in 1984. Neither of these populations has been recently surveyed.

2. Reproductive biology: Reproduction is by seed. The low numbers of successfully reproducing plants at many sites suggests that seed production is a major limitation to population size and distribution of Astragalus scaphoides in Montana. This conclusion is supported by data from several Montana populations over several years, where low percentages of flowering plants and high percentages of aborted flowers have been documented. Browsing of flowering heads (and entire plants), probably by cattle, has been observed at several sites. Bitterroot milkvetch flowers in June and produces fruit from June to July. 
Lesquerella $\mathrm{sp}$. novum I

Undescribed Bladderpod \#1

\section{A. Description}

1. General description: This undescribed Lesquerella is a small, low growing perennial in the mustard family (Brassicaceae). The leaves are mostly in a basal rosette and are shaped like spoons, with a broadened blade and a narrowed petiole. The stem leaves are smaller and sessile. The foliage is covered with short, many rayed hairs which give the leaves a grayish cast. The flowers are borne on stems which hug the ground, several on each stem. The flowers are typical of the family, with 4 green sepals, 4 bright yellow petals, 6 stamens, and a single pistil. The mature fruit is a silique (a fruit with two chambers separated by a membranous partition) which is not much longer than wide and is flattened at right angles to the plane of the partition. A black and white photocopy of a specimen of the plant is included in Appendix $\mathrm{E}$.

2. Technical description: not yet available

3. Diagnostic characters: This taxon resembles Lesquerella carinata to which it keys out in Dorn (1984). The two taxa have technical differences in their fruits (Heidel 1993). The two species are allopatric and Lesquerella carinata is known in Montana only from a small area in the vicinity of Bearmouth in the Garnet Range in Granite County (Vanderhorst 1995b). Lesquerella alpina is the only species of the genus which is known to be sympatric with this undescribed taxon; the former is distinguished by its erect flowering stems, narrow leaves without petioles, and fruits which are not flattened (Heidel 1993, Dorn 1984).

\section{B. Current legal or other formal status}

1. State: The Montana Natural Heritage Program ranks Lesquerella sp. novum I as G2 and S2 (Heidel 1994), signifying that the taxon is imperilled because of rarity. The global and state ranks are the same because the taxon is found only in Montana.

2. Federal

a. U. S. Fish and Wildlife Service: none

b. Bureau of Land Management: proposed watch status (USDI Bureau of Land Management 1993)

c. U. S. Forest Service: sensitive in Region 1 (USDA Forest Service 1994a). 
c. Geographic distribution

1. Species range: The taxon appears to be endemic to Montana.

2. Montana distribution: Seven populations are known, all in Beaverhead County, mostly in the foothills of the Pioneer Mountains and south around Badger Pass and Bannack, but a single outlying population is in the Centennial Mountains.

3. Occurrences in the study area: A population was found in 1992 by Bonnie Heidel on the ridge overlooking Hangman's Gulch and the occurrence was relocated in 1994. The population is on BLM land entirely outside of the present Bannack State Park boundaries, but within the boundaries of the current Recreation and Public Purposes Patent application. An Element Occurrence Record and topographic map showing the precise location are given in Appendix D.

\section{Habitat}

1. Associated vegetation: Lesquerella $\mathrm{sp}$. novum I occurs in both the foothill and sub-alpine zones (Heidel 1993). The population at Bannack is in a foothill setting in a community dominated by mountain mahogany (Cercocarpus ledifolius) and bluebunch wheatgrass (Elymus spicatus). Douglas fir (Pseudotsuga menziesii) and Rocky Mountain Juniper (Juniperus scopulorum) are two subdominant woody species at the site. The undescribed bladderpod usually grows in the most open and exposed microhabitats, rarely close to or in the shade of the dominant canopy species (Heidel 1993). Other forbs in these openings include Allium textile, Arenaria kingii, Castilleja pallescens, Haplopappus acaulis, Mimulus suksdorfii, Penstemon aridus, and another Montana plant species of special concern, Lomatium attenuatum.

2. Topography: The foothills sites in Beaverhead County are on ridges and upper slopes on topography controlled by outcrops of relatively erosion resistant Madison limestone (Heidel 1993). The elevation of these sites ranges from 5,600 to 7,440 feet. At Bannack, the population is on westerly facing slopes below the ridge overlooking Hangman's Gulch, at elevations between 6,300 and 6,400 feet.

3. Soil relations: The soils of most population sites are derived from calcareous formations of the Madison Group (Heidel 1993). The population locations and boundaries in general seem strongly controlled by edaphic substrate. The soil at the Bannack site is a shallow, gravelly clay derived from loose limestone scree. 


\section{E. Population demography and biology}

1. Demographic details: Numerical estimates of population size range from 50 to thousands of plants, and the taxon was considered "common" at two recently surveyed sites. When the population at Bannack was originally discovered only 9 plants were found (Heidel 1993), but over 1,000 plants, covering about 5 acres were estimated in 1994. This population consists of fewer plants, and is confined to a smaller area than the sympatric population of Lomatium attenuatum and the nearby population of sphaeromeria argentea.

2. Reproductive biology: Lesquerella sp. novum I is a small, short-lived perennial which reproduces entirely by seed. Species of Lesquerella are generally cross-pollinated and self-incompatible (Rollins and Shaw 1973). The plants generally flower from late May to late June, with flower and fruit stages often overlapping on the same plant and within an inflorescence due to an indeterminate growth habit (Heidel 1993). The population structure, habitat, and plant habit of Lesquerella sp. novum appear to be very similar to those of Lesquerella carinata var. lanquida, whose population biology has been studied in depth (Greenlee 1994). These bladderpods seem to have populations which are subject to drastic fluctuations in numbers which follow climatic cycles, especially at severe (i.e. hot, dry) sites. 
Lomatium attenuatum Evert

Tapertip Biscuitroot

\section{A. DESCRIPTION}

1. General description: This is a yellow flowered member of the Apiaceae (carrot family). The plants are relatively small and are low growing from a fleshy taproot. The leaves are finely dissected, like lace, and have a petiole which sheaths the stem. The small flowers are borne in a compound inflorescence, called an umbel, with the umbelets (little umbels) having series of inconspicuous bracts below them. The flower parts are in groups of five except for the ovary, which is divided in two. The two parted fruits, called schizocarps, are flattened parallel to the suture and have low ribs on their faces. An illustration of the species is included in Appendix E.

2. Technical species description (quoted from Evert 1983): Plant perennial, short-caulescent, with only one or two cauline leaves, more or less scaberulous, (7-)10-25 cm tall, from an elongated thickened taproot and also occasionally from a several-branched caudex; leaves petiolate, 3-pinnate or ternately 3-pinnate, blades $2.0-11 \mathrm{~cm}$ long, $1.5-10 \mathrm{~cm}$ wide, ovate in outline, the ultimate divisions linear to oblanceolate, 2-5 mm long, 0.5-1.5 mm wide, obtuse to somewhat acute and mucronate; petioles $1.5-5 \mathrm{~cm}$ long, the dilated and scarious sheathing extending to the middle or above; peduncles 1-3(4), scaberulous, exceeding the leaves in fruit, 10-15 cm long; involucre usually absent but occasionally 1 inconspicuous, filiform bract present; fertile rays 5-8, spreading, angled, unequal, (1.5) $3-5 \mathrm{~cm}$ long in fruit; sterile rays 4-8 spreading, $3-10 \mathrm{~mm}$ long in fruit; involucel absent or of $1-6$ inconspicuous linearlanceolate, attenuate, non-connate bractlets, 1-4 mm long; umbellets ca. 15-flowered, only 2-6 developing into fruit; pedicels $3-10 \mathrm{~mm}$ long in fruit; petals $1.5 \mathrm{~mm}$ long including the incurved apex, yellow, obovate, glabrous; styles $1-1.5$ $\mathrm{mm}$ long, spreading or reflexed; ovaries glabrous to slightly scaberulous; fruit oblong-elliptic, glabrous, glossy, 5-8 mm long, 3-5 mm wide, the wings ca. 0.5-0.75 mm wide, narrower than the body; oil tubes prominent, 1 in each interval, 2 on the commissure; carpophore bipartite.

3. Diagnostic characters: Lomatium attenuatum differs from Lomatium cous, which it resembles in habit, leaf dissection, and fruit characters, by having a less conspicuous involucel with tapered rather than rounded bracts and greater overall scabrosity (Evert 1983). Both species are found in Beaverhead County, but they have not been observed growing together at the same site. 


\section{B. PRESENT LEGAI OR OTHER FORMAL STATUS}

1. State: The Montana Natural Heritage Program ranks the species $G 3$ and $S I$ meaning that it is somewhat vulnerable on a global scale due to a limited range, but it is critically imperiled within the state due to extreme rarity (Heidel $1994)$.

\section{Federal}

a. U.S. Fish and Wildlife Service: 3C (UDSI Fish and Wildlife Service 1993); This signifies that the species has "proven to be more abundant or widespread than previously believed and/or....(is) not subject to any identifiable threat."

b. Bureau of Land Management: Lomatium attenuatum is included on the BLM's list of proposed Montana sensitive species (USDI Bureau of Land Management $1993)$.

c. U.S. Forest Service: none

\section{GEOGRAPHIC DISTRIBUTION}

1. Species range: The species is known only from Park County in northwestern Wyoming (Evert 1983, Dorn 1992) and from Beaverhead County in southwestern Montana.

2. Montana distribution: Lomatium attenuatum was first discovered in the state in 1993 by Peter Lesica on BLM land in the Tendoy Mountains (Vanderhorst and Lesica 1994). Additional populations were found in 1994 in the Tendoys (Vanderhorst 1995a, and P. Lesica, pers. commun.) and near Bannack.

3. Occurrences in the study area: A population was located on the limestone ridge above the cemetery, overlooking Hangman's Gulch. Most of the population area lies on BLM land outside of present Bannack State Park boundaries, but a small part is within the park boundaries shown on the USGS Bannack 7.5' quadrangle. Most of the population is within the boundaries of the current Recreation and Public Purposes Patent application. An Element Occurrence Record and topographic map showing the precise location of the population are given in Appendix D.

\section{HABITAT}

1. Associated vegetation: The Beaverhead County populations of tapertip biscuitroot occur in limber pine (Pinus flexilis) and Mountain Mahogany (Cercocarpus ledifolius) communities. 
The Bannack site has a mountain mahogany/bluebunch wheatgrass (Elymus spicatus) habitat type with limber pine occurring as a subdominant species. Associated forbs at this site include Allium textile, Artemisia frigida, Cryptantha celosioides, Delphinium bicolor ssp. novum, Petrophyton caespitosum, Townsendia spathulata, and two other Montana species of special concern, Lesquerella sp. novum I and sphaeromeria argentea.

2. Topography: In Montana, tapertip biscuitroot occurs on mountain and canyon slopes ranging in elevation from 6,200 to 8,500 feet. Near Bannack it grows on the west facing slopes and top of the limestone ridge to the east of Hangman's Gulch between 6,200 and 6,400 feet.

3. Soil relationships: In Montana, Lomatium attenuatum grows in talus and gravelly to rocky soils derived from limestone. Evert (1983) describes the soils where the species is found in Wyoming as "lithosols derived from volcanic material or limestone." It has not yet been found on volcanics in Montana. The soil at the Bannack site is a shallow, loose, gravelly clay derived from Madison limestone, but Lomatium attenuatum usually grows in microsites with substrates better classified as gravel or scree, often next to bedrock outcrops.

\section{POPULATION DEMOGRAPHY AND BIOLOGY}

1. Demographic details: The population at Bannack was estimated to consist of between 1,000 and 10,000 plants and to cover approximately 40 acres. About $50 \%$ of the plants were reproductive and $50 \%$ were vegetative.

2. Reproductive biology: Reproduction is by seed. The flowers appear with the leaves in spring (Evert 1983). At Bannack, most reproductive plants were in a mature fruiting stage with just a few still flowering on the survey date (June 12). Specimens which I collected have between 2 and 30 mature fruits per plant and there is a range in maturity between umbellets on a plant. 
Sphaeromeria argentea Nuttall Chicken Sage

A. Description

1. General description: Commonly called a "sage", this member of the Asteraceae (sunflower family) resembles some species of sagebrush (Artemisia spp.) due to its fragrance, three parted leaves, and small heads of flowers. The plants are often somewhat woody near the base, but are only about six inches or less tall. The leaves are mostly basal and the tiny heads of bright yellow tubular flowers are borne on short pedicels in small terminal clusters. An illustration of the species is included in Appendix E.

2. Technical species description (for Tanacetum nuttallii, a synonym, quoted from Cronquist 1955):

Aromatic perennial with many slender stems $0.5-2 \mathrm{dm}$. tall, often slightly woody at base, fibrous-rooted, or with a short, deliquescently branched taproot; herbage closely gray-tomentose; leaves appearing clustered at the base because of the numerous short sterile shoots, mostly cuneate and 3-toothed or -lobed at the apex, sometimes 4-to 5-lobed or entire, up to about $1.5 \mathrm{~cm}$ long including the slender base; heads several, mostly short-pedunculate in a subcapitate cluster, small, the involucre only 3-4 $\mathrm{mm}$ high, the disk 4-7 mm wide; receptacle glabrous, strongly convex; pappus essentially wanting.

3. Diagnostic characters: The genus sphaeromeria is distinguished from lowland species of Artemisia by the arrangement of its flower heads in capitate clusters vs. racemes or panicles. Sphaeromeria argentea differs from Sphaeromeria capitata (rock tansy) by having leaves which are merely toothed or shallowly lobed rather than deeply lobed and flower heads borne on pedicels in small, somewhat loose clusters rather than sessile in larger dense clusters. Rock tansey, like chicken sage (see below), grows in limestone habitats in Beaverhead County, but the two species have not been seen growing together.

B. Current legal or other formal status

1. State: The Montana Natural Heritage Program ranks Sphaeromeria argentea G? and S1 (Heidel 1994). The undetermined global rank reflects a lack of knowledge on the species distribution and abundance in other states. In Montana, it is considered critically imperiled due to extreme rarity. 
1. Federal
b. U. S. Fish and Wildlife Service: none
a. Bureau of Land Management: none
c. U. S. Forest Service: none

c. Geographic distribution

1. Species range: "central Idaho and adjacent Montana to Wyoming; Nevada (Hitchcock and Cronquist 1973)," also in northwestern Colorado (Weber 1987).

2. Montana distribution: southern Beaverhead County; Sphaeromeria argentea is now known from 5 sites in Montana, in the drainages of Red Rock Creek (near Dell and Matador Ranch), upper Big Sheep Creek, Horse Prairie Creek, and Grasshopper Creek (near Bannack).

3. Occurrences in the study area: Sphaeromeria argentea was found on the same limestone hillside above the cemetery where Lomatium attenuatum was found and much of the population areas of these two species overlap. Most of the population lies outside of the park boundaries as shown on the USGS Bannack $7.5^{\prime}$ quadrangle but within the boundaries of the current Recreation and Public Purposes Patent application. An Element occurrence Record and map showing the precise location of the population are included in Appendix D.

\section{Habitat}

1. Associated vegetation: At Bannack, chicken sage grows in a mountain mahogany/bluebunch wheatgrass (Cercocarpus ledifolius/Elymus spicatus) community with limber pine (Pinus flexilis). Associated forbs include all those listed for tapertip biscuitroot (Lomatium attenuatum) except the undescribed bladderpod (Lesquerella $\mathrm{sp}$. novum I). A population of sphaeromeria argentea on BLM land five miles to the south in the "Rocky Hills" (Vanderhorst 1995c) grows in similar habitat and is also near a population of Lesquerella sp. novum. However, at both sites these two species seem to have mutually exclusive population areas. In the basin of upper Big sheep Creek in extreme southern Beaverhead County, chicken sage grows in a quite different habitat, an alkaline bottomland dominated by Great Basin low sagebrush (Artemisia arbuscula) and greasewood (Sarcobatus vermiculatus) (Vanderhorst and Lesica 1994). 
2. Topography: Four of the sites in Montana are in upland positions on slopes and ridges in the foothills and the fifth is in the basin of upper Big Sheep Creek. The elevations range from about 5,900 to 6,900 feet. At Bannack, chicken sage grows on the westerly facing slopes and top of a limestone ridge at 6,200 to 6,400 feet.

3. Soil relations: Soils at the Bannack site are shallow gravelly clays derived from limestone. Chicken sage also grows in cracks in the limestone pavement.

\section{E. Population demography and biology}

1. Demographic details: Estimates of population size in Beaverhead County range from about 100 plants at upper Big Sheep Creek, to thousands of plants observed in 1994 at each of the Rocky Hills and Bannack sites. The Bannack population was estimated to consist of between 1,000 and 10,000 plants and to cover about 40 acres.

2. Reproductive biology: Reproduction is by seed. The flowering period is in July. All plants seen at Bannack were mature reproductive adults. The plants are probably relatively long-lived. Plants at the nearby Rocky Hills site were infected with a fungus, but its impact on reproduction and survival are not known. 


\section{DISCUSSION}

Although the occurrences of Montana plant species of special concern discussed in this report are mostly outside of the present boundaries of Bannack State Park, and none are in the proposed project areas, there are opportunities for the park to help conserve populations of four rare plant species, and a high quality and diverse native plant community. Populations of three species discussed in depth in this report (Lesquerella species novum I, Lomatium attenuatum, and sphaeromeria argentea) lie within the boundaries of the Recreation and Public Purposes Patent which has been applied for by the park. Several species which were previously tracked by the Montana Natural Heritage Program (Arenaria kingii, Delphinium bicolor ssp. novum, Mimulus suksdorfii, Pediocactus simpsonii, Townsendia spathulata) also grow on the limestone hillside which hosts these species of special concern. The occurrence of so many limestone adapted species at one Montana site is phenomenal and rivals the riches in gold which were taken from the same geological formation in Bannack's boom days. The plants, however, are potentially longer lasting. Approval of the patent application could help insure that future mining, or other human activity, does not threaten this high quality botanical site.

The Montana plant species of special concern discussed in this report are of two kinds. The species which occur on limestone (Lesquerella sp. novum I, Lomatium attenuatum, and Sphaeromeria argentea) are characterized by having relatively large populations which are confined to a particular edaphic substrate. The reproductive levels of these species may be quite high, and the populations seem to fill much of the potential habitat. The species are rare because they grow in an unusual habitat. Because the area of the Madison limestone is limited, and the formation is often associated with deposits of economic minerals such as gold (or the limestone itself), these habitats are most threatened by mining. The open plant communities they support may also be especially vulnerable to invasions of noxious weeds.

Astragalus scaphoides is a different kind of rare plant. It is a regional endemic which grows in sagebrush grasslands, usually in Artemisia tridentata/Elymus spicatus habitat types. These are probably the most common vegetation types in Beaverhead County. Astragalus scaphoides grows in soils derived from various parent materials. There seems to be abundant potential habitat for the species but it is found in only a small percentage of this habitat. Its rarity stems from its low reproductive success, and probably from the impacts of cattle grazing. Populations of the plant are usually small. Penstemon lemhiensis is another sensitive species known from nearby which shares these attributes. Because both of these species are large, upright herbaceous perennials which are palatable to 
cattle and most of their populations are in primary range, they are especially vulnerable to grazing. Penstemon lemhiensis sometimes grows along roadsides where it may be impacted by road construction and maintenance and herbicide spraying.

Although it was not found, there remains some potential for Astragalus scaphoides to occur in Bannack state Park. It is mostly likely to be found to the north of Grasshopper Creek, in sagebrush grassland habitats with well developed soils and southerly aspects. Proposals of any future development or activity which could impact these habitats should consider the potential occurrence of this species. Likewise, projects proposed by the park which could impact nearby populations on BLM and private lands (e.g. access improvements to the east and south) should be planned accordingly.

At present, the quality of native plant habitats in Bannack State Park is improving. The low level of grazing which has occurred in recent years, and suspension of mining and residential activity has allowed native plants to become reestablished in disturbed areas. Although they have relatively low species diversity, functional wetlands have become reestablished over much of the Grasshopper Creek floodplain, and these wetlands are generally in better condition than those outside the park. The conservation of these habitats is especially significant because of Bannack's location in a basin setting; the basins of Beaverhead County are most accessible to cattle and humans and consequently these landscapes are often degraded. Some areas of the park adjacent to roads and development, however, are quite weedy and a program to control aggressive species, such as spotted knapweed, is needed. The loose substrate and open plant community of the limestone hillside above the cemetery make this site especially vulnerable to disturbance and weed invasions, although at this date it remains pristine. Human activity should be minimized on these fragile slopes and cattle should be kept from the park to minimize disturbances and spread of weeds.

Bannack state Park is primarily valued for its historical attributes, but its natural heritage is also unique and impressive. The results of this survey are an indication of a the high level of plant diversity and endemism in the area. This survey should not, however, be considered complete. There are undoubtedly many more plant species which grow in the park besides those listed in Appendix B. There is also a possibility for the occurrence of additional populations of Montana plant species of special concern. Conservation of Bannack's rare plants and unique plant communities should be considered an important management goal in the future. 


\section{LITERATURE CITED}

Barneby, R. C. 1964. Atlas of North American Astragalus. Memoirs of the New York Botanical Garden Vol. 13. Bronx, NY. 2 volumes, $1188 \mathrm{pp}$.

Cronquist, A. 1955. Vascular plants of the Pacific Northwest, part five: Compositae. University of Washington Press, Seattle. $343 \mathrm{pp}$.

Dorn R. D. 1984. Vascular plants of Montana. Mountain West Publishing, Cheyenne, WY. $276 \mathrm{pp}$.

1992. Vascular plants of Wyoming, second edition. Mountain West Publishing, Cheyenne, WY. 340 pp.

Evert, E. F. 1983. A new species of Lomatium (Umbelliferae) from Wyoming. Madrono 30: 143-146.

Geach, R. D. 1972. Mines and mineral deposits (except fuels); Beaverhead County, Montana. Montana Bureau of Mines and Geology bulletin 85. Montana College of Mineral Science and Technology, Butte, MT. $194 \mathrm{pp}$.

Greenlee, J. 1994. The conservation biology of Lesquerella carinata var. languida (Brassicaceae). Unpublished report to The Nature Conservancy. University of Montana, Missoula. $51 \mathrm{pp}$.

Heidel, B. I. 1993. Status review of Lesquerella sp. novum, Butte District, Bureau of Land Management, Montana. Montana Natural Heritage Program, Helena. $40 \mathrm{pp}$.

1994. Montana plant species of special concern. Unpublished Iist. Montana Natural Heritage Program, Helena, MT. $16 \mathrm{pp}$.

Hitchcock, C. L. and A. Cronquist. 1961. Vascular plants of the Pacific Northwest, part 3: Saxifragaceae to Ericaceae. University of Washington Press, Seattle. $614 \mathrm{pp}$.

- 1973. Flora of the Pacific Northwest. University of Washington Press, Seattle, WA. $730 \mathrm{pp}$.

Rollins, R., and E. A. Shaw. 1973. The genus Lesquerella (Cruciferae) in North America. Harvard University Press, Cambridge, MA. $288 \mathrm{pp}$.

U. S. D. A. Forest Service. 1994a. Update of Northern Region sensitive species list. Unpublished List. U.S.F.S. Northern Region, Missoula, MT. 
U. S. D. I. Bureau of Land Management. 1993. Draft list of sensitive and watch plant species in Montana. Unpublished list. Billings, MT. $1 \mathrm{p}$.

U. S. D. I. Fish and Wildlife Service. 1993. Plant taxa for listing as endangered or threatened species; notice of review. Federal Register 58 (188): 51144-51190.

Vanderhorst, J. 1995a. Survey for sensitive plants in the Beaverhead National Forest in the Tendoy Mountains, Beaverhead County, Montana. Unpublished report to the Beaverhead National Forest. Montana Natural Heritage Program, Helena.

1995b. Report on the conservation status of Lesquerel la carinata var. Ianguida, a candidate threatened species: Montana. Unpublished report to the U. S. Department of Fish and Wildlife. Montana Natural Heritage Program, Helena.

1995c. Sensitive plant survey in the Horse Prairie Creek drainage, Beaverhead County, Montana. Unpublished report to the Bureau of Land Management. Montana Natural Heritage Program, Helena.

Vanderhorst, J. and P. Lesica. 1994. Sensitive plant survey in the Tendoy Mountains, Beaverhead County, MT. Unpublished report to the Bureau of Land Management. Montana Natural Heritage Program, Helena. iv $+60 \mathrm{pp}$. plus appendices.

Weber, W. A. 1987. Colorado flora: western slope. Colorado Associated University Press, Boulder. 530 pp. 




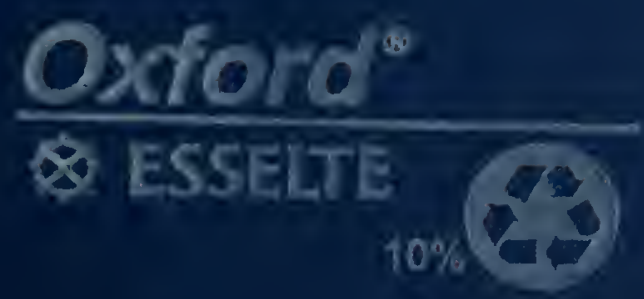


